\title{
CROATIAN EXPERIENCE IN ROAD TRAFFIC NOISE MANAGEMENT - CONCRETE NOISE BARRIERS
}

Saša Ahac, sc. novice, MCE, University of Zagreb, Faculty of Civil Engineering, Fra Andrije Kačića-Miošića 26, 10000 Zagreb, Croatia, e-mail: sahac@grad.hr

Ivo Haladin, assistant, MCE, University of Zagreb, Faculty of Civil Engineering, Fra Andrije Kačića-Miošića 26, 10000 Zagreb, Croatia, e-mail: ihaladin@grad.hr

Stjepan Lakušić, prof., PhdCE, University of Zagreb, Faculty of Civil Engineering, Fra Andrije Kačića-Miošića 26, 10000 Zagreb, Croatia, e-mail: laki@grad.hr

Vesna Dragčević, prof., PhdCE, University of Zagreb, Faculty of Civil Engineering, Fra Andrije Kačića-Miošića 26, 10000 Zagreb, Croatia, e-mail: vesnad@grad.hr

\section{Abstract}

The paper gives an overview of concrete noise barrier application in several EU countries and in Croatia. It describes a process of introducing different noise protection solutions on Croatian market in the phase of intensive motorway construction in recent years. Namely, an extensive motorway network has been constructed in Croatia in the last 10 years. Following the process of motorway construction, noise protection walls have also been erected. Usage of different building materials and installation processes as well as variations in building expenditures has led to a comparative analysis of several types of noise protection solutions (expanded clay, wood fibre) including a new eco-innovative product RUCONBAR, which incorporates rubber granules from recycled waste tyres to form a porous noise absorptive layer.

Keywords: road traffic noise, concrete noise protection wall, recycled rubber

\section{INTRODUCTION}

Noise is one of the most pervasive forms of environmental pollution: it affects our lives at home, work and play, deteriorating our health, causing fatigue and reduced work capacity and interfering with communication, concentration, relaxation and sleep. While noise emanates from many different sources, traffic noise is the most difficult to avoid in society today. Although various measures can be implemented to control and reduce traffic noise (application of "quiet" vehicles, driving speed limitation, regular maintenance of pavement surface, traffic management, etc.), most common solution for the traffic noise problem is the construction of noise protection walls, made from various materials. 


\section{ROMANIAN JOURNAL \\ OF TRANSPORT INFRASTRUCTURE}

Both pressures of people's demands for quieter environments and the growing traffic noise levels result in the increase of the scale of noise barriers used to protect communities. This puts pressure on designers to improve their design and effectiveness. As the most common choice for noise protection, noise barriers concepts continue to strive for innovative and visually acceptable solutions, especially for urban areas.

\section{CONCRETE NOISE BARRIERS FOR ROAD TRAFFIC NOISE MANAGEMENT}

The most common way of dealing with excessive traffic noise levels is the construction of noise barriers between the noise source and the protected area. Nowadays, noise barriers are usually made out of concrete, wood or steel. Due to the strict market conditions and demands for durability and static stability, concrete noise barriers are frequently used across Europe.

Sound absorptive concrete noise barriers incorporate a porous layer that absorbs noise. This layer is usually made out of concrete with wood fibres or small lightweight cementaceous spheres as the aggregate [1]. Sound absorptive layer is supported by bearing layer made from reinforced concrete that provides structural integrity and prevents sound passing through the barrier. In order to provide the maximum sound absorption, the surface of the barrier is usually profiled (Figure 1).

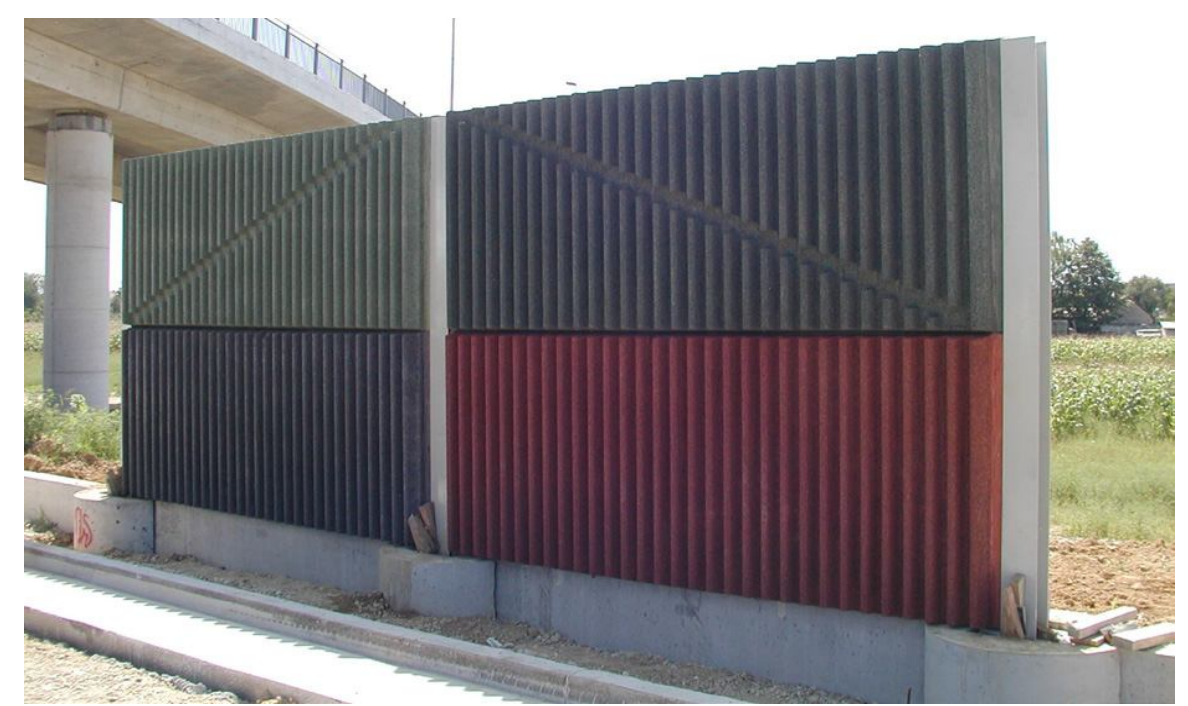

Figure 1. Profiled surface of sound absorbing concrete noise barrier 
ROMANIAN JOURNAL

\section{OF TRANSPORT INFRASTRUCTURE}

In general, concrete noise barriers have many benefits: they are durable, with a life span of at least 40 years, require minimal maintenance and provide low whole life costs. They are also flexible in design and as such can provide elements of architectural interest, which is very important in noise protection design for urban areas.

Another positive aspect of concrete noise barriers, along with their durability and stability, is their price, which is up to 5\% lower than the price of wood barriers, and up to $10 \%$ lower than the price of aluminium barriers [2].

\subsection{Road traffic noise management in EU}

Throughout Europe, noise is an important factor to be considered when it comes to developing, upgrading, and maintaining national road networks. According to the data collected by The Conference of European Directors of Roads (CEDR) via survey on how noise issues are treated in national road administrations around Europe [3], dominating noise mitigation measures on European road networks are proprietary barriers (Figure 2). These noise barriers are predominant measures used to address noise issues on the existing as well as new roads, accounting for up to $90 \%$ of all noise mitigation measures.

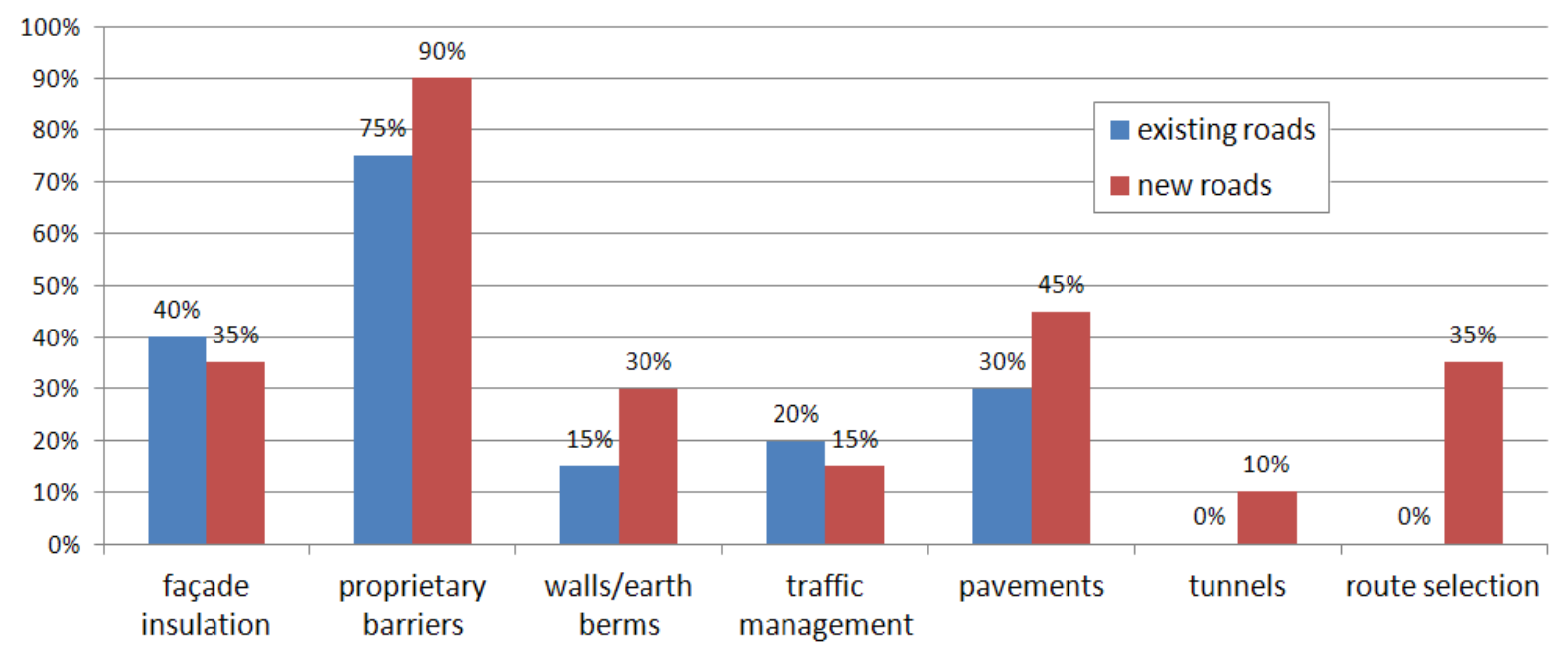

Figure 2. Types of noise mitigation measures in Europe [3]

The results of the same survey showed a wide range of materials that are currently available for the construction of noise barriers, such as concrete, wood, aluminium, brick, glass, wood-concrete, and acrylic (Figure 3). However, the market is dominated by three prominent noise barrier materials: concrete, wood, and aluminium. Additionally, the survey results show that concrete noise 
ROMANIAN JOURNAL

\section{OF TRANSPORT INFRASTRUCTURE}

barriers are a common solution for the road traffic noise problem across Europe [3].

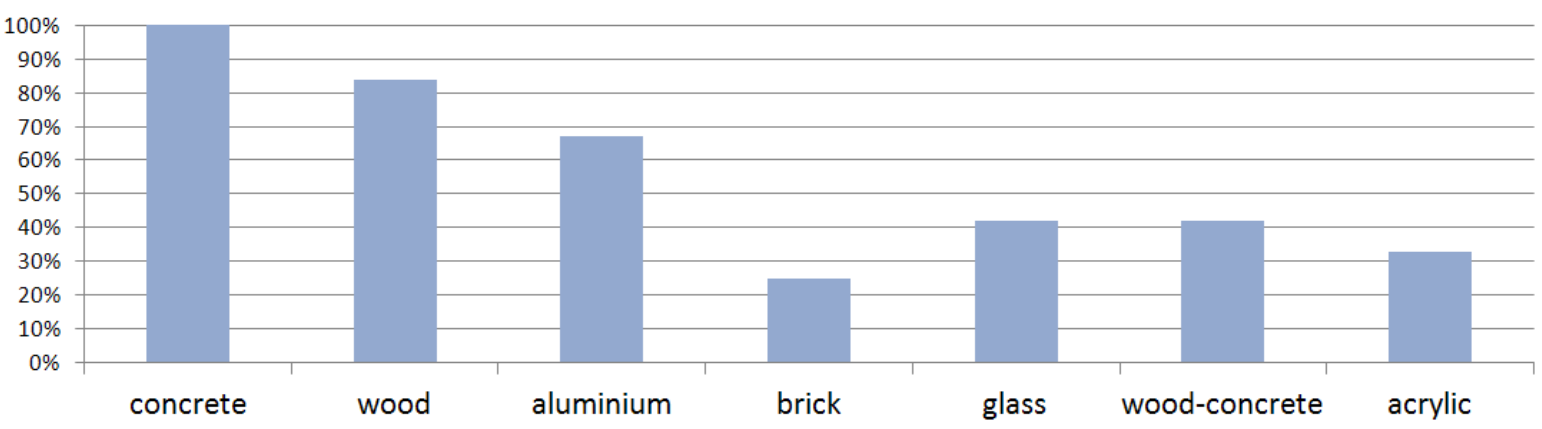

Figure 3. The composition of noise barriers and percentage of CEDR member states using that barrier type [3]

\subsection{Introduction of concrete noise barriers in Croatia}

Predominant noise mitigation measures on new, as well as existing roads in Croatia are noise barriers. Until the end of 2007, $158000 \mathrm{~m}^{2}$ of noise barriers were constructed on new highways [4], comprising wood, aluminium, and glass or acrylic. Construction elements for these barriers were mainly imported, since their production technology was undeveloped.

During 2006, researchers from the Faculty of Civil Engineering, University of Zagreb, together with experts from two Croatian companies that had the technology for the production of precast concrete construction elements, introduced the sound absorbing concrete noise barriers to the local market. These noise barriers had a porous layer made out of concrete with expanded clay as the aggregate. Soon they became the common solution for road traffic noise problems in Croatia; from 2007 until 2010, sound absorptive concrete noise barriers that were entirely made by local companies and with mainly local materials have taken over the local market (Figure 4). 
ROMANIAN JOURNAL

OF TRANSPORT INFRASTRUCTURE

Saša Ahac, Ivo Haladin, Stjepan Lakušić, Vesna Dragčević,

Croatian experience in road traffic noise management - concrete noise barriers

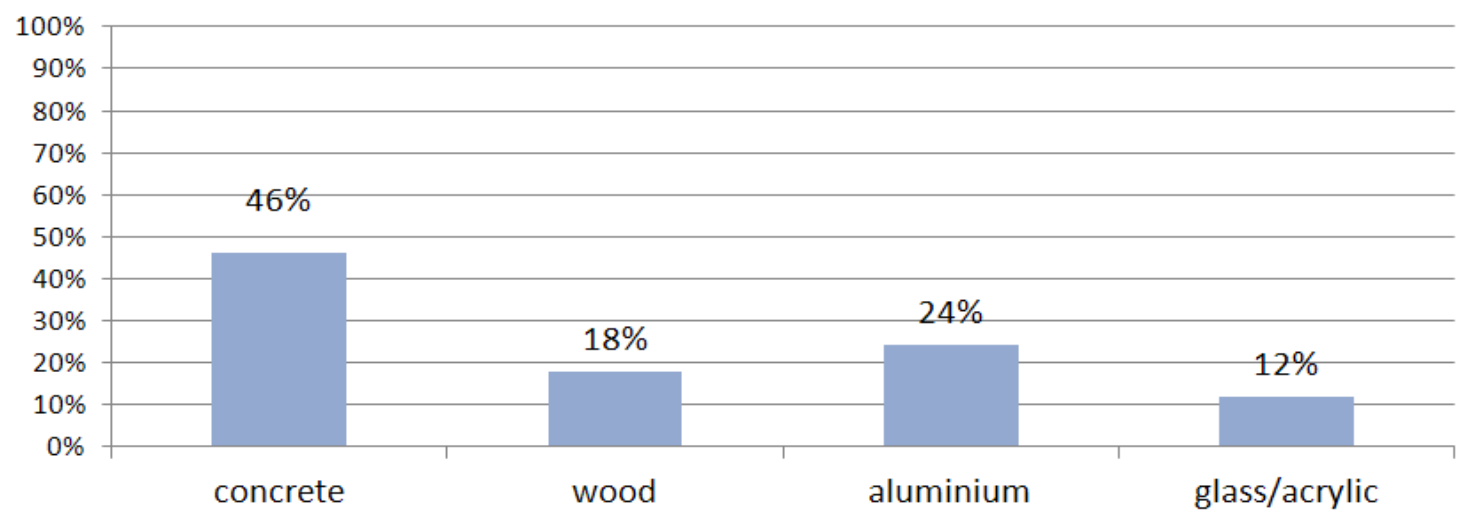

Figure 4. Types of noise barriers in Croatia built from 2007 to 2010

Planned further investments in transport infrastructure in Croatia should result in $750 \mathrm{~km}$ of new roads, as well as $404 \mathrm{~km}$ of modern railways [4]. According to the provided data, the need for effective noise barriers will surely rise, and the noise absorbing concrete barriers will certainly keep their place on the market.

\section{COMPARATIVE ANALYSIS OF CONCRETE NOISE BARRIERS}

Common materials used today in the construction of noise absorbing layer are wood fibres and expanded clay granules. Using these materials is contrary to sustainable development as their production causes significant changes in the ecosystem. Namely, the production of wood fibre requires severe deforestation, and manufacturing expanded clay also causes significant depletion of natural resources irreversibly leaving stripped and devastated environment.

Porous lightweight concrete absorption layer that was introduced to Croatian market in 2006 was comprised using the expanded clay granules, so researchers from the Faculty of Civil Engineering, University of Zagreb, continued research aimed at finding alternative materials for absorption layer of concrete noise barriers. In order to replace natural resources, whose usage degrades the environment and natural balance, a new approach for forming the absorbing layer was developed: a new product named RUCONBAR (Rubberised Concrete Noise Barriers), which incorporates rubber granules from recycled waste tyres to form a porous sound absorptive layer (Figure 5). 


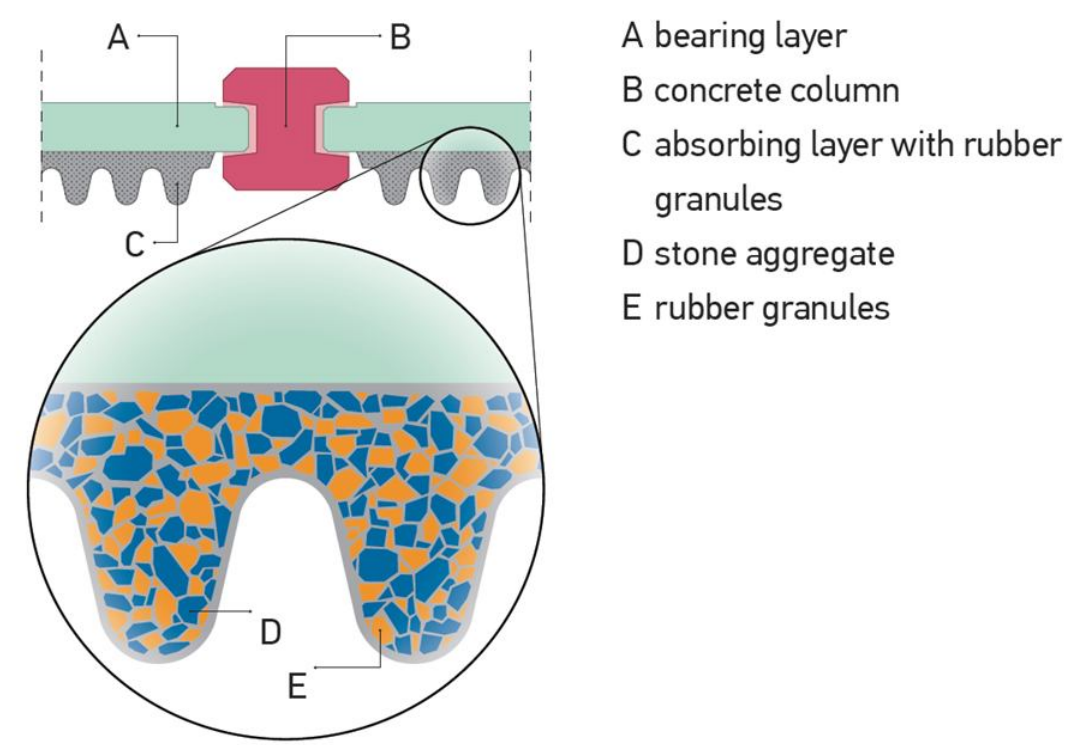

Figure 5. RUCONBAR's elements

Hereinafter results of noise absorption properties tests of this new product are given, as well as comparison between new and existing products on the market in terms of acoustic performance and the results of LCA.

\subsection{Sound absorption}

The most important property of the described noise protection barriers is the ability of noise absorption. Acoustical absorption is the property of any material that changes the energy of sound waves into another form. Due to the fact that RUCONBAR contains untested material in its absorbing layer, the testing of absorbing properties was conducted in order to determent its sound absorbing behaviour. Sound absorption tests of noise protection barriers with absorbing layer made of expanded clay (LIADUR) and wood-concrete (FASETON) was also conducted, on samples with similar absorbing surface cross sections and with the thickness of absorbing layer of $10 \mathrm{~cm}$ (Table 1) [5].

Table 1. Single-number rating of sound absorption [6]

\begin{tabular}{|c|c|c|}
\hline Product & $\mathrm{DL}_{\alpha}[\mathrm{dB}]$ & Sound absorption class \\
\hline Wood-concrete barrier & 7 & $\mathrm{~A} 2$ \\
\hline Expanded clay barrier & 4,4 & $\mathrm{~A} 2$ \\
\hline Recycled rubber granules & 6 & $\mathrm{~A} 2$ \\
\hline
\end{tabular}


According to the measurement results, RUCONBAR noise protection barrier has been listed under A2 class of sound absorption, based on the sound absorption value $\left(\mathrm{DL}_{\alpha}\right)$ of $6 \mathrm{~dB}$. Conducted testing indicate satisfying absorption properties and the possibility of their improvement through further development with the goal of reaching class A3 of sound absorption. The competitive products can achieve higher classes of sound absorption, which greatly depends on the cross section of the absorption surface, as shown in Table 2.

Table 2. Single-number rating of sound absorption for different cross sections

\begin{tabular}{|c|c|c|c|c|}
\hline Product & $\begin{array}{c}\text { Shape of } \\
\text { surface }\end{array}$ & $\begin{array}{c}\text { Absorbing } \\
\text { layer }[\mathrm{cm}]\end{array}$ & $\mathrm{DL}_{\alpha}[\mathrm{dB}]$ & $\begin{array}{c}\text { Sound absorption } \\
\text { class }\end{array}$ \\
\hline \multirow{2}{*}{$\begin{array}{c}\text { Wood- } \\
\text { concrete } \\
\text { barrier }\end{array}$} & block & 9 & $8-11$ & $\mathrm{~A} 3$ \\
\cline { 2 - 5 } & low wave & 11 & $8-11$ & $\mathrm{~A} 3$ \\
\cline { 2 - 5 } & high wave & 12 & $>11$ & $\mathrm{~A} 4$ \\
\hline \multirow{2}{*}{$\begin{array}{c}\text { Expanded } \\
\text { clay barrier }\end{array}$} & flat & 15 & $4-8$ & $\mathrm{~A} 2$ \\
\cline { 2 - 5 } & trapezoidal & 11 & $8-11$ & $\mathrm{~A} 3$ \\
\cline { 2 - 5 } & high wave & 13 & $>10$ & $\mathrm{~A} 3$ \\
\hline
\end{tabular}

In order to achieve higher classes of sound absorption, different optimization prototypes of RUCONBAR were also designed and tested. Optimization prototypes differed in thickness and shape of their absorbing layer: flat, undulating (high wave), and trapezoidal surface (Figure 6).

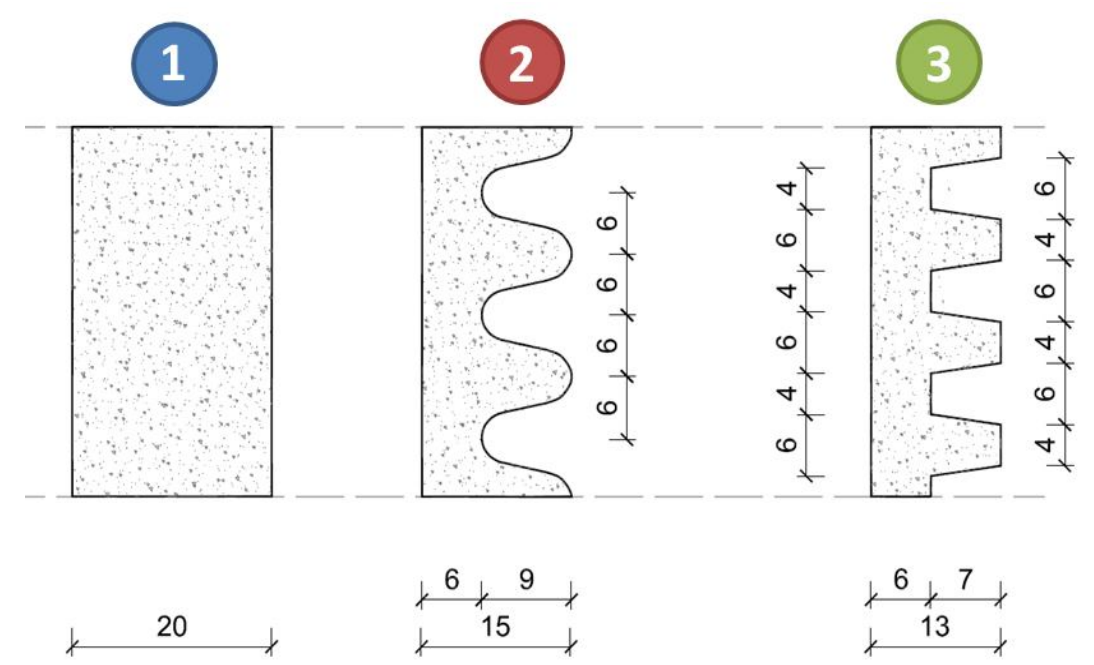

Figure 6. Cross sections of optimization prototypes' absorbing layer 
ROMANIAN JOURNAL

\section{OF TRANSPORT INFRASTRUCTURE}

Results of these tests, namely the sound absorption coefficients as (used to express sound absorption capability of tested materials by turning energy of the sound wave into heat), single-number rating of sound absorption $\mathrm{DL}_{\alpha}$, and class of absorptive performance for each optimization prototype are shown in Figure 7 and Table 3 [7].

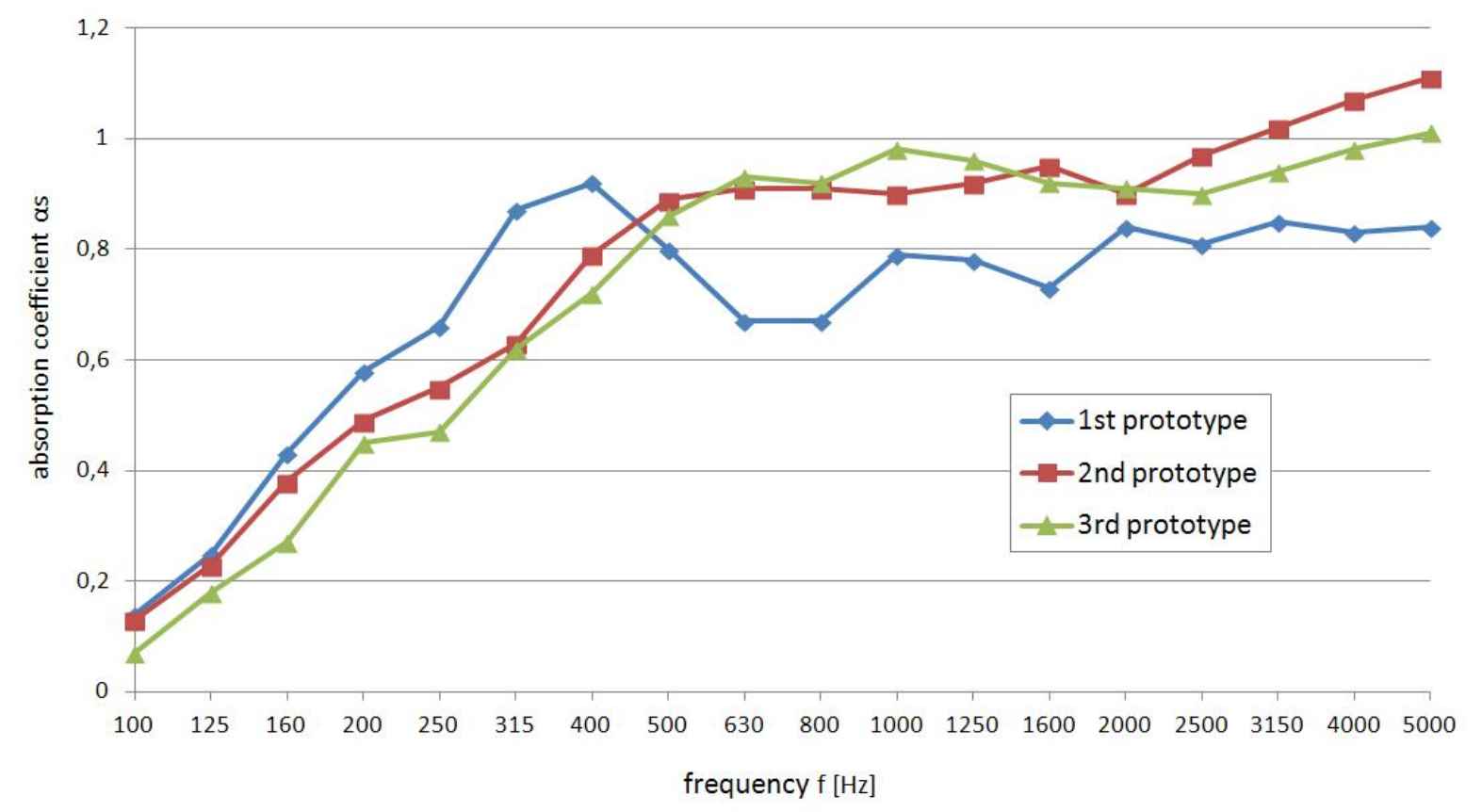

Figure 7. Sound absorption coefficients for different optimization prototypes

According to the measurement results, RUCONBAR noise protection barrier has been listed under A2 and A3 class of sound absorption, depending on the shape of the absorbing layer's surface. The highest single-number rating of sound absorption $\mathrm{DL}_{\alpha}$ was achieved with second optimisation prototype - high wave (Table 3).

Table 3. Single-number rating of sound absorption for different cross sections of RUCONBAR

\begin{tabular}{|c|c|c|c|c|}
\hline Product & $\begin{array}{c}\text { Shape of } \\
\text { surface }\end{array}$ & $\begin{array}{c}\text { Absorbing } \\
\text { layer }[\mathrm{cm}]\end{array}$ & $\mathrm{DL}_{\alpha}[\mathrm{dB}]$ & $\begin{array}{c}\text { Sound } \\
\text { absorption class }\end{array}$ \\
\hline \multirow{3}{*}{ RUCONBAR } & flat & 20 & 6 & $\mathrm{~A} 2$ \\
\cline { 2 - 5 } & high wave & 15 & 8,7 & $\mathrm{~A} 3$ \\
\cline { 2 - 5 } & trapezoidal & 13 & 8,6 & $\mathrm{~A} 3$ \\
\hline
\end{tabular}




\subsection{Life cycle analysis}

In order to evaluate the environmental impact of new noise protection barrier, Life Cycle Analysis was conducted. The goal of this analysis was a comparative life cycle assessment of noise protection barriers with expanded clay (LIADUR) and RUCONBAR: form raw materials acquisition and processing, production, mounting and their dismantling/disposal, so called "cradle-to-grave" approach. Analysis was made using ECO-it software, and analysed products were barriers with $7 \mathrm{~cm}$ of average absorption layer thickness.

As it is shown Figure 8, the main contributions are due to production process (which includes acquisition and production of raw materials and their transport to location) while maintenance and disposal process have less impact. For disposal of noise protection barrier, "the most probable" scenario was assumed. Unfortunately, only $10 \%$ of construction waste produced in Croatia is recycled and reused, while $90 \%$ is still land filled [8].

For RUCONBAR, disposal scenario of $90 \%$ of absorption layer recycled and reused for a new absorption layer was used. Recycled rubber wasn't included in inventory as input material: it was considered as a final product of recycling end-of-life tires, so only energy consumption of mechanical grinding process and transport to the production site of noise protection barrier were included in the analysis.
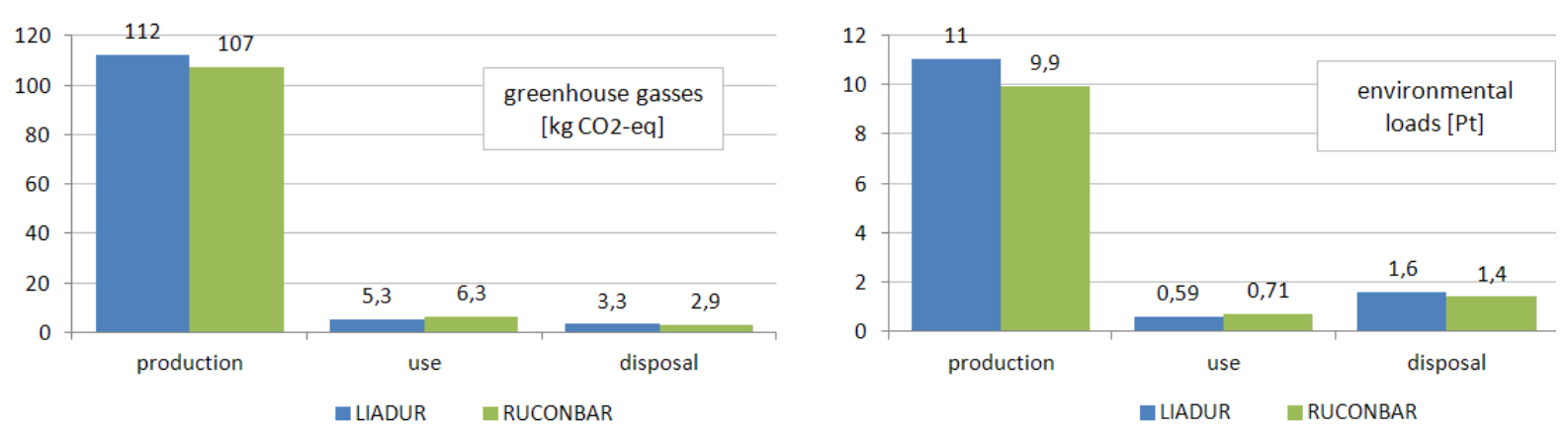

Figure 8. Greenhouse gasses and environmental load [8]

The results of this environmental assessment show lower environmental load for noise protection barrier with recycled rubber, in comparison with noise protection barriers with expanded clay. As both types of noise barriers have the same bearing layer, the absorption layer determined this outcome. The comparative analysis of this relevant element as an independent unit is shown in Figure 9. 
ROMANIAN JOURNAL

OF TRANSPORT INFRASTRUCTURE

Saša Ahac, Ivo Haladin, Stjepan Lakušić, Vesna Dragčević,

Croatian experience in road traffic noise management - concrete noise barriers

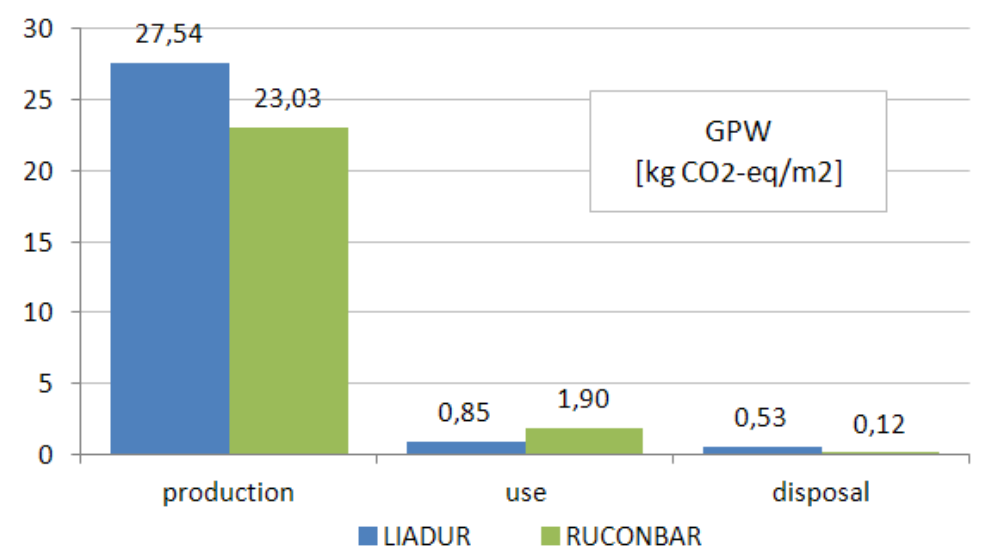

Figure 9. Global Warming Potential (GWP) [8]

\section{CONCLUSIONS}

Common noise mitigation measures on new, as well as existing roads in EU and in Croatia are sound absorbing concrete noise barriers with absorbing layer made from concrete with wood fibres of expanded clay granules. Using these materials is contrary to sustainable development as their production causes significant changes in the ecosystem. In order to replace these natural resources, a new product named RUCONBAR (Rubberised Concrete Noise Barriers), which incorporates rubber granules from recycled waste tyres to form a porous sound absorptive layer, was developed and tested.

Results of sound absorption tests placed RUCONBAR under A2 and A3 class of sound absorption, depending on the thickness and the shape of the absorbing layer's surface. Results of LCA show lower environmental impact of noise protection barrier RUCONBAR, in comparison to noise protection barrier which contains expanded clay.

Acknowledgment

Presented research was performed within the project RUCONBAR- Rubberized concrete noise barriers (No. ECO/10/277317/SI2.595674), under the umbrella of the Eco-Innovation initiative and Executive Agency for Competitiveness and Innovation (CIP) framework. Authors would like to thank Croatian Ministry of Education, Science and Sport for their support since preliminary research for RUCONBAR project was performed within the project "The Development of New Materials and Concrete Structure Protection Systems", 082-08221612159, and "Noise and vibration of tram and railway tracks", 082-0000000-2185. 


\section{ROMANIAN JOURNAL OF TRANSPORT INFRASTRUCTURE}

\section{REFERENCES}

[1]. B. KOTZEN, C. ENGLISH: "Environmental noise barriers: a guide to their acoustic and visual design”, $2^{\text {nd }}$ ed., Taylor \& Francis, Abingdon, Oxfordshire, UK, 2009.

[2]. "Statistik des Larmschutzes an Bundesferstrasen, Bundesministerium fur verkehr, Bau und Stadtentwicklung”, Bonn, Germany, 2006.

[3]. "Noise management and abatement", Conference of European Directors of Roads (CEDR), Paris, France, 2010.

[4]. S. LAKUŠIĆ, D. BJEGOVIĆ, A. BARIČEVIĆ, M. SERDAR, I. HALADIN: "Usage of waste tyre recycling products in noise barrier manufacturing - RUCONBAR", Proceedings of the Congress of Croatian Builders 2012: Construction as lever of Development, organised by the Croatian Association of Civil Engineers, Cavtat, Croatia, 15-17 November 2012.

[5]. S. LAKUŠIĆ, D. BJEGOVIĆ, I. HALADIN, A. BARIČEVIĆ, M. SERDAR: "RUCONBAR - innovative noise protection solution made of recycled waste tyres", Proceedings of the 20th International Scientific Conference "TRANSPORT 2011", MTC Academic Journal, issue 3 (X-76 - X-82), 2011.

[6]. S. LAKUŠIĆ: "How to obtain EU project without an EU partner - example of RUCONBAR project from the EU program CIP Eco-Innovation", Proceedings of the 12th International scientific conference on planning, design, construction and building renewal "iNDiS 2012", organised by the University of Novi Sad, Faculty of Technical Sciences, Department of Civil Engineering and Geodesy, Novi Sad, Serbia, November 28-30, 2012.

[7]. "RUCONBAR Rubberized concrete noise barriers (No. ECO/10/277317/SI2.595674): Report on acoustic and mechanical properties of optimization prototypes”, INSTITUT IGH, Zagreb, Croatia, 2012.

[8]. "RUCONBAR Rubberized concrete noise barriers (No. ECO/10/277317/SI2.595674): Comparative Life cycle analysis of RUCONBAR with other similar solutions”, DLS Ltd., Zagreb, Croatia, 2012. 